Журнал «Герспективитаінноваціїнауки»

(Серія«Гедагогіка»), Серія«ГТихологія», Серія «Медицина»

№5(5) 2021

УДК 378:615.8

https://doi.org/10.52058/2786-4952 -2021-5(5)-276-283

Драгунов Дмитро Миколайович доктор філософії, старший викладач кафедри фізичної реабілітації Національного університету «Чернігівська політехніка», вул. Шевченка, 95, м. Чернігів, 14000, тел.: (093) 317-04-04, e-mail: drahunovdm@gmail.com, https://orcid.org/ 0000-0002-5305-7815

Ридзель Юрій Миколайович кандидат економічних наук, доцент кафедри фізичної реабілітації Національного університету «Чернігівська політехніка», вул. Шевченка, 95, м. Чернігів, 14000, тел.: (063) 620-52-80, e-mail: yuriy_ridzel@ukr.net, https://orcid.org/0000-0002-1812-0436

Супронюк Марина Володимирівна старший викладач кафедри фізичної реабілітації Національного університету «Чернігівська політехніка», вул. Шевченка, 95, м. Чернігів, 14000, тел.: (063) 184-68-16, e-mail: kiyashkomarina221@gmail.com, https://orcid.org/0000-0002-0834-1702

Зайщев Володимир Олексійович кандидат педагогічних наук, доцент, завідувач кафедри фізичної реабілітації Національного університету «Чернігівська політехніка», вул. Шевченка, 95, м. Чернігів, 14000, тел.: (095) 212-52-78, e-mail: v.zaytsev@ukr.net, https://orcid.org/0000-0003-1176-4623

\title{
ІННОВАЦІЇ В ПОКРАЩЕННІ ФІЗИЧНОГО СТАНУ СТУДЕНТІВ ВИЩИХ НАВЧАЛЬНИХ ЗАКЛАДІВ У ПРОЦЕСІ СПЕЦІАЛЬНОЇ ФІЗИЧНОЇ ПІДГОТОВКИ
}

Анотація. Удосконалення та покращення фізичного стану суспільства в Україні наразі перебуває в симбіозі, оскільки низький рівень якісної фізичної підготовки населення впливає на тривале життя населення та рівень економічної стабільності в країні. 3 огляду на те, що в умовах швидкого темпу життя відбувається системне збільшення психологічного, емоційного та фізичного навантаження на людину, питання про покращення фізичного стану здобувачів вищої освіти набувають особливої гостроти та актуальності.

Враховуючи тенденцію спаду фізичної підготовки підростаючого покоління, яка також пов'язані з станом здоров'я населення, особливо в умовах сучасної пандемії COVID-19, негативно впливає на розвиток якісної підготовленості не тільки майбутніх правозахисників нашої країни, а і всього населення. Приділення більшої уваги саме фізичному та спортивному стану і відродження обов'язкового спорту у країні призведе до здорової нації та економічного розвитку держави.

Досліджено сутність поняття «спеціальної фізичної підготовки» та 
проаналізовано досвід багатьох науковців у цій сфері і запропоновано власне трактування цієї дефініції, яке грунтується на основній базовій спортивній підготовці та складається 3 рівня фізичних здібностей $і$ розвиток функціональних можливостей у процесі підготовки фахівця.

У статті розглянуто інноваційний процес спеціальної фізичної підготовки завдяки покращенню фізичних якостей, проходженням методів, які спрямовані саме на розвиток витривалості, сили, швидкості, спритності та гнучкості. Знайдено підходи до покращення рівня спеціальної фізичної підготовки студентів у вищих навчальних закладах та запропоновані інноваційні шляхи покращення спортивного стану студента завдяки силовим та швидким якостям, які у подальшому підвищать рівень фізичного стану та дадуть змогу краще виконувати професійну діяльність у правоохоронній сфері.

Ключові слова: фізичний стан, фізичні якості, студент, спеціальна фізична підготовка.

Drahunov Dmytro Mykolaiovych Doctor of philosophy, senior Lecturer, Department of Physical Rehabilitation, Chernihiv Polytechnic National University, Shevchenka St., 95, Chernihiv, 14000, tel.: (093) 317-04-04, e-mail: drahunovdm@gmail.com, https://orcid.org/ 0000-0002-5305-7815

Rydzel Yurii Mykolaiovych PhD in Economics, Associate Professor Department of Physical Rehabilitation, National University "Chernihiv Polytechnic", Shevchenka St., 95, Chernihiv, 14000, tel.: (063) 620-52-80, e-mail: yuriy_ridzel@ukr.net, https://orcid.org/0000-0002-1812-0436

Suproniuk Maryna Volodymyrivna Senior lecturer Department of Physical Rehabilitation, Chernihiv University, Shevchenka St., 95, Chernihiv, 14000, tel.: (064) 184-68-16, e-mail: kiyashkomarina221@gmail.com, https://orcid.org/0000-0002$0834-1702$

Zaitsev Volodymyr Oleksiiovych $\mathrm{PhD}$ in Pedagogical Sciences, Associate Professor, Head of the Department of Physical Rehabilitation, Chernihiv Polytechnic National University, Shevchenka St,, 95, Chernihiv, 14000, tel.: (095) 212-52-78, e-mail:v.zaytsev@ukr.net, https://orcid.org/ 0000-0003-1176-4623

\section{INNOVATIONS IN IMPROVING THE PHYSICAL CONDITION OF STUDENTS OF HIGHER EDUCATIONAL INSTITUTIONS IN THE PROCESS OF SPECIAL PHYSICAL TRAINING}

Abstract. Improving and improving the physical condition of society in Ukraine is currently in symbiosis, as low levels of quality physical training affect the long life of the population and the level of economic stability in the country. Given the fact that in the conditions of fast pace of life there is a systematic increase of 
psychological, emotional and physical load on a person, the issue of improving the physical condition of higher education students becomes especially acute and relevant.

Given the declining trend of physical training of the younger generation, which is also related to the health of the population, especially in the current pandemic COVID-19, negatively affects the development of quality training not only future human rights defenders in our country but the entire population. Paying more attention to the physical and sports condition and the revival of compulsory sports in the country will lead to a healthy nation and economic development of the state.

The essence of the concept of "special physical training" is studied and the experience of many scientists in this field is analyzed and the own interpretation of this definition is offered.

The article considers the innovative process of special physical training through the improvement of physical qualities, the passage of methods that are aimed at the development of endurance, strength, speed, agility and flexibility. Approaches to improving the level of special physical training of students in higher education institutions and innovative ways to improve the athletic condition of students due to strength and speed, which will further improve the physical condition and enable better professional performance in law enforcement.

Keywords: physical condition, physical qualities, student, special physical training.

Постановка проблеми. В сучасних умовах охорона здоров'я знаходиться на першому рівні по збереженню здорової нації та виступає ключовим елементом національної безпеки. Підростаюче покоління, в нашому випадку студенти вищих навчальних закладів мають бути захищені у всіх сенсах цього значення.

Рівень фізичного стану студента повинен бути на належному рівні, якого так не вистачає на даний час, бо саме спортивно підготовлений фахівець зможе чітко і швидко вирішувати завдання пов'язані з фізичним навантаженням, особливо у правоохоронній діяльності, що у свою чергу зіграє вирішальним фактором забезпечення законності правопорядку та боротьбі зі злочинністю.

Аналіз останніх досліджень і публікацій. Питання спеціальної фізичної підготовки досліджуються вітчизняними та іноземними вченими. Значний внесок у дослідження особливостей спеціальної фізичної підготовки розглянуто в роботах В.В. Бондаренко, І.М. Гриньова, В.А. Данильченко, С.М. Решко, В.В. Чернякова та інших.

Водночас питання спеціальної фізичної підготовки та його особливостей достатньо різноманітний й багатоплановий, тому вимагають подальших досліджень.

Мета дослідження. Метою даної статті $є$ дослідження особливостей спеціальної фізичної підготовки, що передбачає науково обгрунтувати та покращити процес спеціальної фізичної підготовки студентів вищих 
навчальних закладів з урахуванням рівня розвитку їх фізичних якостей.

Викладення основного матеріалу дослідження. Фізичний стан людини являється важливим критерієм у спеціальній фізичній підготовці. Перш за все кожна людина на землі піклується за стан свого здоров'я протягом усього свого життя. Сучасні темпи розвитку цивілізації покращують життя людства, але водночас знижують його рухову активність, що в сукупності з негативною екологією завдає великої шкоди організму людини. Збільшилося число захворювань, знижується активність імунної системи, особливо у пандемію. Зниження рухової активності - це один 3 багатьох негативних чинників, що перешкоджають нормальній плідної життєдіяльності людини. Всі показники за якими визначають рівень фізичного стану (показники серцево-судинної системи, маси тіла, віку тощо) обов'язково супроводжуються здоровим способом життя. Фізичний стан презентує особистість людини, стан його здоров'я, статуру й конституцію, функціональні можливості організму, фізичну працездатність і підготовленість [1].

Особлива увага фізичної підготовки приділяється студентам, які навчаються на правоохоронній діяльності. Рухова і спеціальна активність повинна супроводжуватись здоровим способом життя - це головне завдання усіх закладів вищої освіти. Протягом навчання здобувач вищої освіти повинен зміцнювати своє здоров'я та підвищувати свої фізичні якості, а заклади освіти повинні у свою чергу забезпечувати навчання сучасними програмами 3 використанням новітніх технологій.

Розглядаючи більш детально термін «спеціальна фізична підготовка», слід відзначити який вагомий внесок у іi розуміння зробили вчені, які запропонували сутність та визначення дефініції у табл. 1.

Таблиця 1

Аналіз та визначення сутності спеціальна фізична підготовка (СФП)

\begin{tabular}{|c|c|}
\hline Автор & Визначення поняття \\
\hline $\begin{array}{c}\text { Боровицький С.Б., } \\
\text { Булах С.М. }\end{array}$ & $\begin{array}{l}\text { Визначають СФП як педагогічно спрямований процес } \\
\text { спеціалізованої } \\
\text { діяльнозичної пі підгтовленості до до прецифічними професійними характеристиками. }\end{array}$ \\
\hline Муллер А.Б. & $\begin{array}{l}\text { Визначає СФП рівнем розвитку фізичних здібностей, } \\
\text { можливостей органів і функціональних систем, що безпосередньо } \\
\text { визначають досягнення в обраному виді спорту. }\end{array}$ \\
\hline Костюкевич В.М. & $\begin{array}{l}\text { Наголошує на тому, що СФП вирішує завдання виховання } \\
\text { специфічних здібностей, завдяки яким спортсмен досягає успіху в } \\
\text { обраному виді спорту. }\end{array}$ \\
\hline $\begin{array}{l}\text { Огарь Г.О., } \\
\text { Санжаров В.А., } \\
\text { Ласиця В.I. }\end{array}$ & $\begin{array}{l}\text { Звертають увагу на те, що основним завданням СФП є } \\
\text { підведення спортсмена до головних змагань у стані максимальної } \\
\text { спортивної підготовленості (спортивної форми). }\end{array}$ \\
\hline $\begin{array}{c}\text { Бондаренко В.В., } \\
\text { Решко С.М. }\end{array}$ & $\begin{array}{l}\text { СФП забезпечує підготовку фахівців Національної поліції } \\
\text { України } 3 \text { високим рівнем усебічної фізичної підготовленості, } \\
\text { здатних ефективно, з максимальною безпекою для власного життя } \\
\text { і здоров'я здійснювати силове затримання правопорушника у } \\
\text { випадках, коли той чинить фізичний опір. }\end{array}$ \\
\hline
\end{tabular}


Журнал«Герспективита інновації наукцљ

(Серія«Гедагогіка», Серія«Гtиххологія», Серія«Медицин®»

№5(5) 2021

Сосіна Ю.В.

Наголошує, що СФП - це процес, спрямований на виховання фізичних якостей і розвиток функціональних можливостей, що створюють сприятливі умови для вдосконалення всіх сторін підготовки.

Джерело: складене автором на основі $[1 ; 2 ; 3 ; 4 ; 5 ; 6]$.

Враховуючи існуючі підходи до трактування категорії «спеціальна фізична підготовка» вважаємо необхідним дати власне трактування даної категорії. Так, під СФП розуміють рівень фізичних здібностей і розвиток функціональних можливостей у процесі підготовки фахівця, здатного ефективно і продуктивно здійснити силове затримання правопорушника.

Фізична підготовка студента щільно пов'язана 3 його спортивною спеціалізацією, а спеціальна фізична підготовка студента об'єднує багато спортивних направлень, які пов'язані з силовими i швидкими якостями, включають елементи рукопашного бою, больові і задушливі прийоми.

Основним завданням СФП є підвищення силових та швидких якостей, підвищення резервних можливостей організму для створення можливостей збільшувати навантаження, також розвивати і вдосконалювати бойові навички для затримки правопорушника з запобігання помилок у їх техніки виконання.

Вивчення програми $з$ дисципліни спеціальна фізична підготовка в перш за все охоплює проходження знань та компетенцій для забезпечення ефективного здійснення управлінської діяльності та організації фізичної підготовки у системі службової підготовки поліцейських, а також суттєве вдосконалення професійно важливих умінь і навичок застосування заходів фізичного впливу, що необхідні для протидії злочинцям під час виконання оперативних та службових завдань.

Для досягнення мети під час занять зі спеціальної фізичної підготовки реалізують загальні та спеціальні завдання, які представлені на схемі процесу спеціальної фізичної підготовки для студентів спеціальності «Правоохоронна діяльність» на рис.1.

Вивчення дисципліни «Спеціальна фізична підготовка» для спеціальності «Правоохоронна діяльність» полягає у формуванні знань та умінь при затриманні правопорушника, бути постійно у гарній спортивній формі та зміцнювати здоров'я студентів.

При вивченні курсу дисципліни СФП, слід розподілити заняття на три групи, які складаються 3 методів оволодіння знаннями, методів засвоєння техніки прийомів фізичного впливу та методів спрямованих на розвиток фізичних якостей. Всі ці методи тісно пов'язані у підготовці студентів і забезпечують ефективне інноваційне вирішення завдань у подальшій роботі.

Розвиток фізичних якостей складається 3 проходженням методів, які спрямовані саме на розвиток витривалості, сили, швидкості, спритності та гнучкості.

Безперервний метод характеризується одноразовим виконанням тренувальної роботи. 
Повторний метод характеризується багаторазовим виконанням вправи 3 інтервальним відпочинком.

Інтервальний метод передбачає виконання вправ 3 інтервалами на відпочинок і в невеликій кількості. Вправи можна виконувати у різних режимах темпу.

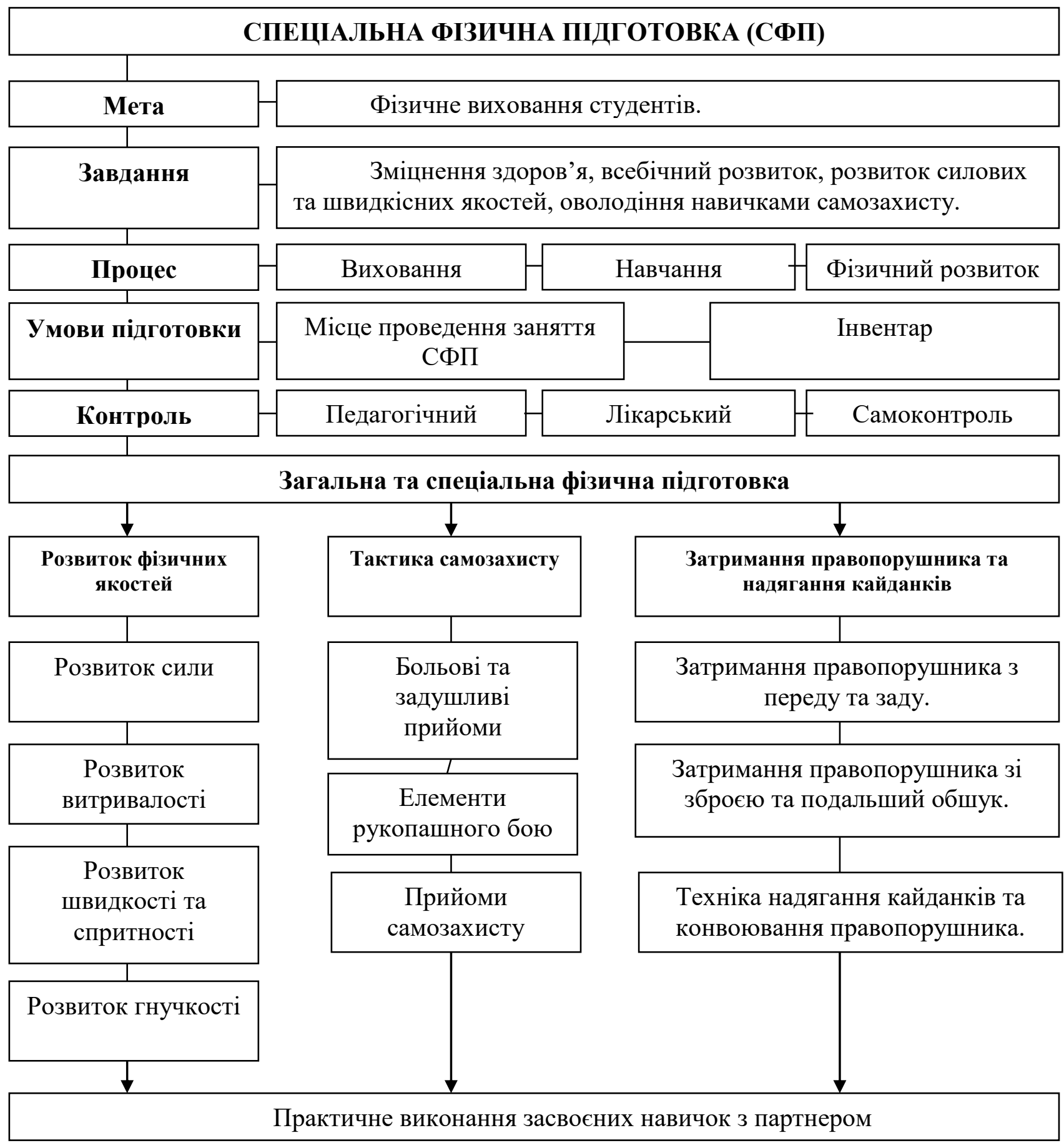

Pис. 1. Прочес спеціальної фізичної підготовки студентів спеціальності «Правоохоронна діяльність» 
Журнал«Герспективитаінновації наукиљ

(Серія«Гедагогіка», Серія«ГЕихологія», Серія «Медицин»

№5(5) 2021

Коловий метод передбачає послідовне виконання різних вправ на різних станціях, які дають можливість вирішити різні завдання фізичної підготовки і розвивають як силову витривалість, так і швидкісну підготовку. Розміщують станції і добирають вправи таким чином, щоб той, хто тренується, послідовно виконував різні за характером і переважною спрямованістю вправи [1].

Ігровий метод забезпечує високу результативність і високий рівень прийняття рішень. Всі особливості ігрового тренування дають змогу бути ініціативним, сміливим, наполегливим, координаційним, сильним, швидким та миттєво мислити, що призведе до швидкого і рішучого виконання тактичних завдань. При цьому методі навантажень організм переключається на іншу фізичну активність і відпочиває.

Змагальний метод виступає як спосіб проявити свої спортивні здібності виражені фізичним навантаженням та психологічними можливостями. Лише у процесі змагань можна вийти на рівень граничних функціональних проявів і оволодіти здатністю виконувати таку роботу, яка під час тренувальних занять виявляється непосильною. [7].

Вивчення техніки самозахисту і затримання правопорушника - це процес оволодіння технікою прийомів фізичного впливу, який складається 3 трьох основних етапів: ознайомлення, розучування і удосконалення.

Ознайомлення - це утворення попереднього і головне правильного уявлення про рухову дію і чіткого розуміння ії структури. Для ознайомлення 3 прийомом фізичного впливу необхідно назвати прийом, показати техніку виконання пояснюючи у яких випадках його застосовувати і як він впливає на організм та потім.

Розучування здійснюється 3 метою вміти виконувати прийом у його цілому вигляді. Розучування прийомів обов'язково виконується з партнером підвідними вправами та розділяється на частини. Підвідні вправи використовуються для полегшення оволодіння технікою прийому шляхом планомірного засвоєння більш простих, 3 порідненою координаційною структурою. При не складності прийому, його можливо розучувати відразу в цілому.

Удосконалення - проходження цього етапу проходить у практичному виконанні різних вправ з партнером та удосконалення: виконання прийому повільно, з прискоренням, з напругою, розслаблено, з фіксацією у кінцевій частині траєкторії руху, у швидкому темпі [1].

Під час усього навчального-спортивного процесу слід контролювати свій стан здоров'я самостійно, або звертатися за консультацією до спеціалістів.

Висновки. Викладене дає підстави стверджувати, що успішне проходження дисципліни спеціальна фізична підготовка дає можливість постійно бути у високій спортивній формі, оволодіти знаннями, уміннями і навичками самозахисту, вміти застосовувати їх при силовому затриманні суспільно небезпечних осіб у випадках виникнення для цього правових підстав. Постійний розвиток і вдосконалення професійно важливих фізичних 
якостей, які виховують психічну стійкість, зосередженість, сміливість, рішучість, впевненості у власних силах і можливість слідкувати за станом свого здоров'я, що є найважливішим у теперішній час.

\section{Лimepamypa:}

1. Бондаренко В.В., Решко С.М. Фізичний стан курсантів Національної академії внутрішніх справ. Юридична психологія. №2. 2015. С. 180-188.

2. Електроний ресурс https://dduvs.in.ua/wpcontent/uploads/files/Structure/library/student/ fp.pdfZminu u ecstrenii dopomozi [Changes in emergency care]. Retrieved from http://bit.ly/2UUcheU

3. Костюкевич В.М. Теорія і методика тренування спортсменів високої кваліфікації. Навчальний посібник. Вінниця: «Планер», 2007. С.- 273.

4. Муллер А.Б. Фізична культуа. https://stud.com.ua/4068/meditsina/fizichna_kultura

5. Огарь Г.О., Санжаров В.А., Ласиця В.І. Спеціальна фізична підготовка кваліфікованих борців протягом макроциклу в умовах вищого навчального закладу. Проблеми фізичного виховання і спорту. 2010. № 12. С. 86-88.

6. Сосіна В.Ю. Фізична підготовка спортсменів. Тези лекції для студентів. Львів. 2013.

7. Спеціальна фізична підготовка як складова частина службово-прикладної i професійної підготовки співробітників органів внутрішніх справ. Гігієна і контроль на заняттях спеціальною фізичною підготовкою і спортом : фонд. лекція. І. П. Закорко, О. В. Журавель, Ю. В. Логвіненко. Київ. Знання України, 2010. 27 с.

\section{References:}

1. Bondarenko, V.V., Reshko, S.M. (2015). Fizichnij stan kursantiv Nacional'noï akademiï vnutrishnih sprav [Physical condition of cadets of the National Academy of Internal Affairs]. Juridichna psihologija - Legal psychology, 2, 180-188 [in Ukrainian].

2. Changes in emergency care Retrieved from http://bit.ly/2UUcheU [in English].

3. Kostjukevich, V.M. (2007). Teorija i metodika trenuvannja sportsmeniv visokoï kvalifikaciï [Theory and methods of training highly qualified athletes].Vinnicja: «Planer» [in Ukrainian]

4. Muller, A.B. Fizichna kul'tua [Physical cult]. Retrieved from https://stud.com.ua/4068/ meditsina/fizichna_kultura [in Ukrainian].

5. Ogar', G.O., Sanzharov, V.A., Lasicja, V.I. (2010). Special'na fizichna pidgotovka kvalifikovanih borciv protjagom makrociklu v umovah vishhogo navchal'nogo zakladu [Special physical training of qualified wrestlers during the macrocycle in a higher education institution]. Problemi fizichnogo vihovannja i sportu - Problems of physical education and sports, 12, 86-88 [in Ukrainian].

6. Sosina, V.Ju. (2013). Fizichna pidgotovka sportsmeniv [Physical training of athletes]. L'viv [in Ukrainian].

7. Zakorko, I. P. , Zhuravel', O. V. , Logvinenko, Ju. V. (2010). Special'na fizichna pidgotovka jak skladova chastina sluzhbovo-prikladnoï $i$ profesijnoï pidgotovki spivrobitnikiv organiv vnutrishnih sprav. Gigiena $i$ kontrol' na zanjattjah special'noju fizichnoju pidgotovkoju $i$ sportom [Special physical training as an integral part of service-applied and professional training of law enforcement officers. Hygiene and control in special physical training and sports]. Kiïv. Znannja Ukraïni [in Ukrainian]. 